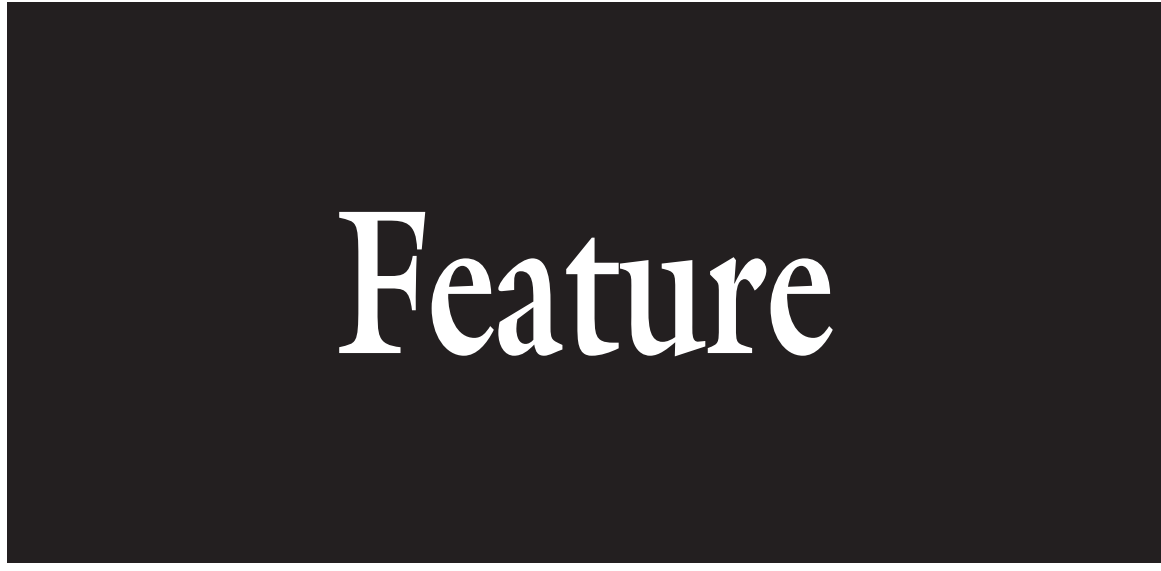

\title{
Getting Started: Writing the Course Syllabus
}

\author{
Mary Lewnes Albrecht ${ }^{1,2}$
}

\section{AdDitional Index wORDs. Teaching}

SUMMARY. You are assigned a new course to teach and you need to prepare the course syllabus. Regardless of the institution where you work, the syllabus speaks about you as a teacher and mentor. The syllabus also can set the tone for the semester and can get students excited or turned off to your course. Where do you start? Some universities and colleges will have strict guidelines; others provide none. Even when using common sense while preparing the syllabus, many items are overlooked. This feature article provides examples on the various components from the foundational, such as presenting basic course and instructor information, to the more difficult statements, such as appreciation of diversity and student conduct.

A fter 28 years of being a faculty member, of which 12 have been as an administrator, this article represents "practicing what you preach." I often remind senior faculty members that we need to share how we teach. A good place to start is with the course syllabus. When assigned a new course to teach, chances are that we start with the syllabus of a similar course we once took. In the era of accountability, universities, colleges, and departments are taking a more active approach in discussing the curriculum, determining student outcomes, and organizing courses around these outcomes. Therefore, an instructor of a new course, whether a graduate teaching assistant, a new assistant professor, or an experienced full professor, should converse with the

Department of Plant Sciences, College of Agricultural Sciences and Natural Resources, University of Tennessee, Knoxville, TN 37996-4500

I thank Dr. Mark Windham, Distinguished Professor in the Department of Entomology and Plant $\mathrm{Pa}$ thology, University of Tennessece, for allowing the inclusion of the excerpt from his course syllabus

${ }^{1}$ Professor and Associate Dean for Academic Programs ${ }^{2}$ Corresponding author. E-mail: mlalbrecht@utk.edu. department head or chair, and the undergraduate coordinator or graduate director, to determine what the expectations are for the newly assigned course.

Depending upon the institution of higher education, there may be specific guidelines on how a syllabus is to be constructed (D'Antonio, 2007). Some institutions consider the syllabus a contract between the university and students, and they give extensive review to syllabi to ensure that correct and appropriate information is shared with students. For those at institutions that do not have strict guidelines, this article is intended to provide assistance in organizing your thoughts about the syllabus and to ensure that you present your pedagogy to students in an organized, positive, and responsible manner.

\section{Purpose of the course syllabus}

The syllabus is a formal means of communicating information to students. It goes beyond dissemination of the course outline of topics and important dates. Hess and Whittington (2003) reviewed educational literature regarding the course syllabus and material from the National Council for Accreditation of Teacher Evaluation (NCATE) to conclude that the “...syllabus becomes an integral part of a professor's course that encourages and supports the sort of interactivity and active, purposeful, effective learning that we want to promote...[A] course syllabus will provide the framework and direction sought by professors and students, thus creating the contract that both parties desire, when the syllabus is provided to students and discussed with students on the first day of classes." While Hess and Whittington refer to the syllabus as "the contract," many institutions do not view the syllabus as a legal contract. It is a guide to the course. In the student handbook of my institution, Hilltopics (most universities have some sort of student handbook in hard copy or online) clearly states that all syllabi must be distributed to students and include "...such matters as required readings, the approximate number of tests, the basis for the final grade with regard to the value to be placed on class recitation, major tests, minor tests, research papers, etc. The syllabus should also state the time and location of the faculty member's office hours. Once such basic principles for the conduct of the course have been announced, faculty should later make changes only after careful consideration and consultation with the students" (University of Tennessee, 2008).

Because the syllabus may be the student's first introduction to you as an instructor, you need to pay attention not only to how you construct, but also how you write the syllabus (D'Antonio, 2007; Wasley, 2008). Some simple things to consider include:

Provide positive direction by using "rewarding terms" as opposed to putting guidelines in negative, "punishing terms."

Provide details - explain your expectations of the students and let them know what to expect from you.

Proofread and use spell check - a syllabus that is riddled with errors sends the wrong message to students about the quality of work they should provide you. If you demonstrate sloppy work, the students will provide sloppy work.

Avoid the minimalist approach lack of information about the course 
may convey the impression you are neither interested in teaching students nor interested in the course. Today's student is from the millennial generation, which is accustomed to receiving detailed directions (Taylor, 2006).

Detailed guidelines for written assignments such as journal article reviews, laboratory reports, and topical papers lets students know you care about the quality of their work and want them to be professional about it.

Provide information about all scheduled events for the course. Does your syllabus set the bar or leave the door open for the "I did not know there was a test today" defense? Provide not only test dates, but also include due dates for assignments, homework, laboratory reports, and other work, and then review the information on the first day of the semester to make sure the information is shared in at least two ways - orally and visually. This will also allow you to explain how you handle assignments turned in after the due date or missed exams and quizzes.

If you expect student participation, explain what constitutes participation. If participation is not addressed, students might get the message they do not need to come to class. If you require attendance, you might explain why. If you include participation as part of the grade, again, explain why and how it is measured.

\section{Sections of the course syllabus}

Course information. The course number and title, the term to which the syllabus applies, and scheduled time and location should appear at the top of the syllabus. Wasley (2008) reported on a study that indicated that "...42\% of syllabi examined did not include when the class was held and $81 \%$ neglected to mention how many credit hours students would receive." Basic course information is more critical for freshman level courses because they will be less familiar with campus. You may encounter a student who just got lost on the first day and ended up in the wrong room at the wrong time.

Contact information. Contact information for the professor and teaching assistants (if there are any) should be given on the first page. For each instructor, provide the name, office location, telephone numbers, e-mail address, fax number, office hours, and secretary contact information (if applicable). A simple reminder regarding telephone numbers: do not forget to give area codes. Students come to campus with cell phones from area codes that differ from the campus area code.

Some faculty will provide students with a personal cell or home phone number. Just remember that students are active into the early hours of the morning while you may already be asleep. You may want to indicate you will not accept calls after a certain hour.

Table 1. Description of a junior-level, 1-credit-hour public horticulture course as given in the university catalog and an expanded description given on a syllabus.

From the University of Tennessee undergraduate catalog

Study of the history, value and role of public garden conservatories. Management, operations, and display of plants in controlled environments for research, conservation, and public education and entertainment. Prerequisite: Plant Sciences 226

\section{Expanded description}

This course will cover the history, value and role of public garden conservatories. Many of the historic structures were built for estates for the nouveau riche of the late 19th and early 20th centuries, the period referred to as the Gilded Age. Since this era, events in U.S. history have altered their mission from purely display of exotic plants for pleasure or production of cut flowers and fruits for the owners. The impact of society and economics on the vitality of conservatories will be explored, including the contemporary movement toward sustainability, making conservatories "Green," in early 21 st century terms, and the use of conservatories primarily for entertainment, not education.

Management, operations and display of plants in controlled environments for botanical and horticultural research, conservation, and public entertainment will be discussed. Allowing the public into these greenhouse structures creates challenges for pest and plant management.

Therefore, this course is intended to provide you with insights into the history and management of conservatories, since many public gardens have such structures on their grounds. If you continue your career in public horticulture, you may well find yourself managing a conservatory or using one for educational programs.

Plant Sciences 226 is a prerequisite to this course. This course is for students enrolled in the Plant Sciences - Public Horticulture major. Other students who may be interested in enrolling in this course include Biology, Agricultural Science - Agricultural Education, and Ecology majors.

Table 2. Learner objectives from a junior-level, 1-credit-hour public horticulture course.

\section{Upon completion of the course, the student will be able to:}

- Describe the historical periods of conservatory construction and the economic and social factors that influence their utilization

- Develop a conservatory mission statement

- Summarize strategies used to develop educational displays and appropriate plant signage

- Develop an understanding of the management of the facility and plants contained therein, and personnel needed to operate a conservatory.

- Describe contemporary measures being taken to make conservatories "green"

- Describe an integrated pest management plan for a conservatory 
Course Description AND objectives. Many students do not read the course description in the catalog, or know whether the course is required or elective. They may look at an advising checklist, a degree audit report, or timetable that lists only course numbers and titles. Including the description on the syllabus provides the student a broad overview of the course (Table 1). Because you will not be limited by the restrictions of the university catalog, you can expand on the description to provide a more in-depth description and place the course in context with the curriculum.

Preparing course objectives also fits the course within the curriculum and explains what skills and knowledge will be gained by taking the course (Table 2 ). For required lower division courses, providing the objectives helps students understand why the course is required. If you are responsible for a lower division (freshman or sophomore) course that is a prerequisite to an upper division (junior or senior) course, discuss with other instructors their needs to ensure that the necessary principles are covered. List these courses and provide an explanation of how your course provides the foundation material needed for students to succeed in the upper division courses.
Course outline. The course outline should evolve over time as the discipline changes with new discoveries or to meet new needs of the curriculum. Even if the course is a general survey course used to meet general education distribution requirements for the university or college, the reading assignments need to be updated if there is a new edition of the textbook or a new textbook is selected.

While the first example in Table 3 demonstrates a minimalist approach, it also conveys to the student that you may not have read the textbook and do not review the syllabus from year to year. Simply using dates and revising them from year to year will at least make you look at the semester calendar; they do change. It also, at the very least, implies to the students that you do recognize there is a semester calendar.

The course outline should include each class date, the topic that will be covered each day, and the reading assignment that you expect the students complete before class to be adequately prepared for the session (Table 3). Actually going through the exercise of reviewing the semester calendar and adjusting the class schedule each semester sends a subtle yet strong message to students that you care about teaching.
Other useful information to provide includes due dates for assignments, review dates for tests, quiz and test dates, and the final exam date and time. If the courses has a laboratory, provide the schedule and laboratory report due dates. In highly detailed course outlines, instructors may also include add/drop deadlines, school closings (days when classes are not held), and any seminars or workshops that the instructor wants students to attend.

Depending upon syllabus guidelines for your institution, after the semester course outline, you may add a statement that indicates that while every effort will be made to adhere to the given outline, changes may be necessary due to unanticipated events, such as illness of the instructor or inclement weather, or the pace of the class. Each class will have a unique character. Some years, students quickly and easily grasp concepts; other years, they do not. The pace may need to change due to the character of the total group of students. Regardless of the reason for the change in outline, the change should be discussed with the students before ending any plans. This is most critical when discussing moving the date of a major exam or project due date. As an instructor, you need to keep in mind

Table 3. Minimalist and detailed approaches to the course outline on a syllabus.

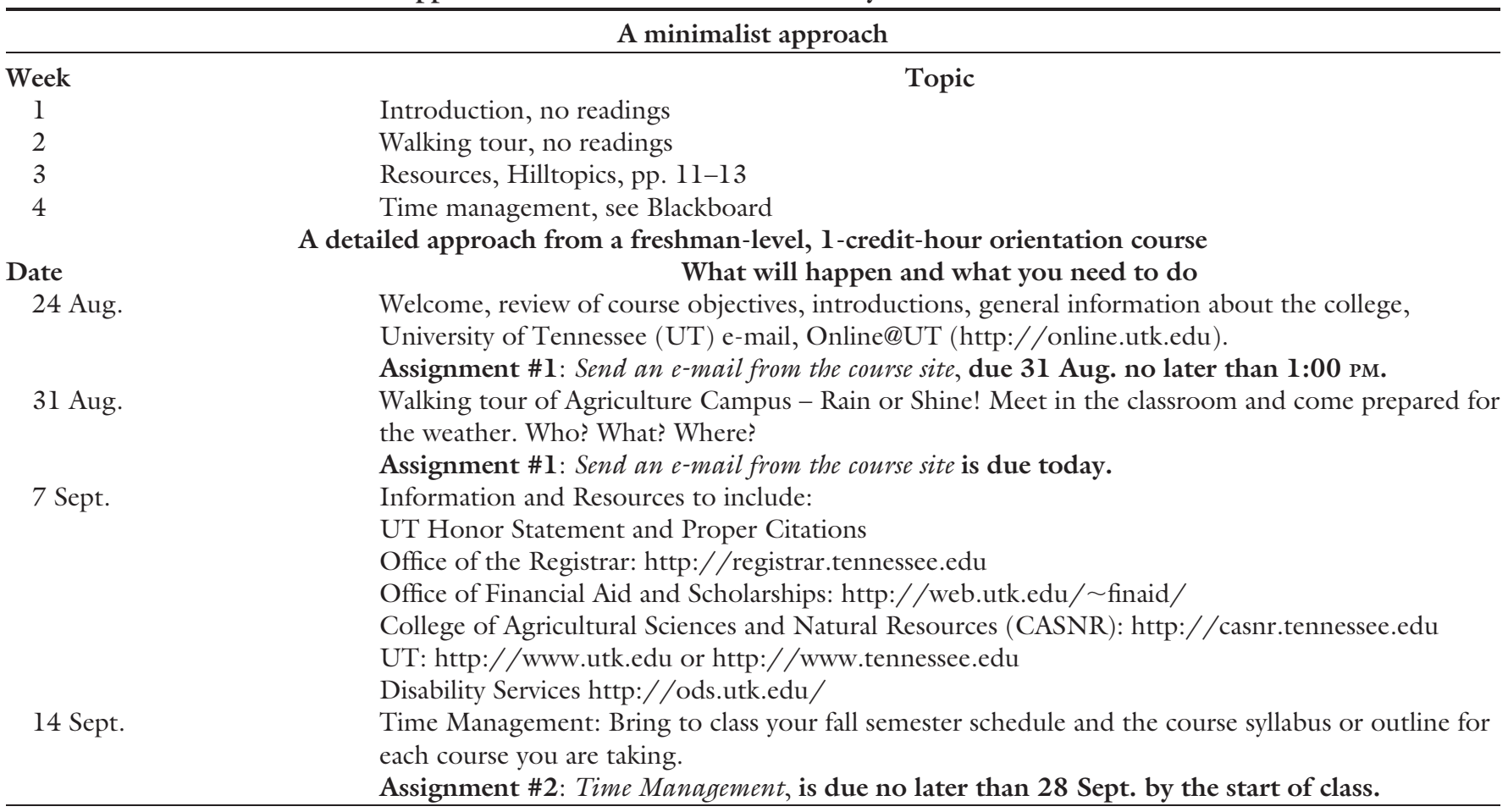


that your class is not the only course in which the student is enrolled for that particular term.

The University's CONDUCT statement. Most universities have a student conduct or honor statement. It frequently appears on the admissions application. When the student applies, she or he agrees to acceptable academic conduct. However, with many universities going to an online application, this statement may not be as visible.

Many universities have recommended guidelines regarding the inclusion of such a statement on the course syllabus. By adding it to your course syllabus, you now have the opportunity to discuss plagiarism and other areas of academic conduct in your course and the implications for the profession.

An issue related to plagiarism is the reuse of a paper on a topic that relates to more than one course. For example, a student writes a paper on the history of the potato famine in Ireland for a world history class and then modifies and submits it in a plant pathology course. If you find this unacceptable, clearly state on your course syllabus that you do not accept papers completed for another course (Table 4). Most university student conduct standards will include a statement similar to faculty being “...responsible for defining, in specific terms, guidelines for preserving academic integrity in a course..." (University of Tennessee, 2008). Reuse of a paper is a matter of academic integrity.

OTHER RECOMMENDED COURSE STATEMENTS. Each university may suggest or require inclusion of additional topics on the course syllabus. If your institution does not have set guidelines, areas to consider addressing are diversity; students' rights; the use of technology to include specific software, e-mail, course management system, laptops in the classroom, and personal response systems; off-campus field experiences and activities; appropriate attire for laboratory and other course experiences; and specifics relating to student conduct, including class absences or arriving late to class (Table 4).

In regard to absences and late arrivals, this is one of those life skills that employers now expect students to learn while attending college. Employers expect employees to call in sick, coordinate vacations, and request time for family responsibilities. Therefore, you can expect your students to e-mail, text message, "call in sick," or provide advance notice of an absence due to a job

Table 4. Sample recommended course statements about reusing papers, off-campus field work, diversity, technology, student conduct, and student disability accommodation.

Statement on Reusing Papers

Students are expected to complete assignments independently from others, unless otherwise specified. I expect each paper, laboratory report, review or similar written assignment to be an original work. Materials created for other courses are not acceptable because each course has different course objectives and learner outcomes.

\section{Off-Campus Field Work}

There are two required all-day field trips (see course outline). You are expected to work outdoors and participate in all activities. No open-toed or open-back shoes are acceptable. Clothing may be soiled, therefore, dress appropriately. Transportation will be provided using university vans. However, should you decide to use your own vehicle, you must present to me, l-week before the field trip or other off-campus activity, a valid driver's license and current liability insurance.

\section{Diversity Statement}

The university is concerned that you learn to function in an intercultural workplace and in an international setting. We value diversity and believe it enriches the educational experience by providing you with the opportunity to learn from individuals who differ from yourself. Diversity strengthens communities and the workplace by preparing you for citizenship in an increasingly complex, pluralistic society, and by fostering mutual respect and teamwork.

\section{Technology Use in the Course}

You need access to a word processor, e-mail, and the Internet for this course. This course is on Online@UT. ${ }^{\mathrm{z}}$ I assume your university e-mail address is active because I do communicate using e-mail; if your university account is not activated, activate it! You do not want to miss an e-mail alert I may send you regarding this course. All course materials will be posted to Online@UT. Read the materials posted for the class session. Send reflective journal entries to me via e-mail or use the Digital Dropbox. You should have access to Microsoft Word ${ }^{y}$ (preferred word processor). I will use the reviewing toolbar to provide feedback and will return your work via e-mail.

\section{Student Conduct}

You are expected to show respect for your classmates, me and guest presenters. All digital devices, such cell phones and personal digital assistants (PDAs), will be turned off and remain in backpacks or purses. No phone calls will be accepted during class. No text messaging will occur during class. No use of laptops for purposes other than directed instruction is allowed. No reading the school newspaper or doing crossword puzzles. You are expected to come to class prepared for the day's activity and to actively participate by answering questions and doing in-class group work.

If you anticipate missing a class, please notify me before your absence. If you are ill with the flu or other contagious illness, it is better to miss class than expose classmates to your illness. It is your responsibility to obtain class notes from a classmate.

\section{Accommodation of Student Disabilities}

The Office of Disability Services (ODS) assists all students, with documented disabilities, and provides appropriate accommodations. The ODS is the designated office that obtains and files disability-related documents, certifies eligibility for services, determines reasonable accommodations, and develops plans for the provision of such accommodations. If you require accommodations, please contact them at (555) 867-0000 or (555) 867-1000 fax, e-mail: ods@mycollege.edu. ${ }^{x}$

${ }^{z}$ University of Tennessee course management system by Blackboard, Inc. (Washington, DC)

${ }^{y}$ Microsoft Inc. (Redmond, WA)

xTelephone and fax numbers, and e-mail address are fictitious 
Table 5. Presentation of assignments from freshman level, 1-credit-hour orientation and junior-level, 1-credit-hour public horticulture courses taught by the author.

From a freshman-level course

All assignments must be written using proper sentence structure and punctuation. Each assignment will be evaluated on content and writing. Outlines are not acceptable, unless specified. All assignments must be typed. Use double line spacing, Times Roman or comparable 12-point font, and 1-inch $(2.5 \mathrm{~cm})$ margins (top, bottom, left, and right). All assignments are due on the day specified as listed in the course outline.

Full assignment descriptions and requirements are posted at the course site in Online@UT. ${ }^{\mathrm{z}}$ If you have any questions, do not hesitate to contact me.

Assignment \#1: Send me an e-mail from course web site, complete no later than 1:00 PM on Wednesday, 31 Aug. Point Value = 25 points.

Assignment Objective: To verify you activated your university e-mail account and can log into Online@UT, the course management system web site.

Assignment \#2: Time Management, due 28 Sept. by the start of class. Point Value = 100 points.

Assignment Objective: To monitor use of time over the course of one week, to identify "time wasters," and to learn how to more effectively manage my time.

Assignment \#3: Personal Interview of Academic Adviser, due 19 Oct. by the start of class. Point Value = 100 points.

Assignment Objective: To locate your adviser's office and get to know him/her as a person, as well as your adviser.

Assignment \#4: Career Choice, due 26 Oct. by the start of class. Point Value $=100$ points.

Assignment Objectives: 1) To write in clear, active voice your career goals and identify one company or graduate or professional school that can meet your career goals. 2) Learn how to research information about a company or graduate or professional school. 3 ) To locate Hollinsgworth Auditorium, site of many college events.

Assignment \#5: 5 Things I Now Know That I Did not Know in 5 Aug.; Things I Wish We Had Covered, due 16 Nov. by the start of class. Point Value $=75$ points.

Assignment Objective: To reflect on material presented in this course and identify things learned to help the instructor strengthen the course.

From a junior-level course

Since the course only meets for 5 weeks, you are expected to attend all class sessions. I fully expect you will read the assigned materials before coming to class. You are expected to complete a reflective journal for each class session submitted no later than $1 \mathrm{~h}$ before the next class session begins. Information on how to write a reflective journal is posted to the course management site and at the end of this syllabus. Information on writing a reflective journal will be discussed during the first class session. The last course journal entry is due no later than 13 Feb. (1 week after the last class session). The course grade is based on class participation (25\%) and weekly course journal entries $(75 \%)$. Course participation includes contributing to discussion either when called upon by me or volunteering when questions are raised by me or classmates.

${ }^{z}$ University of Tennessee course management system by Blackboard, Inc., Washington, DC.

interview or student competition. Of course, if you have a statement regarding absences, you would also include how you expect students to handle missed classed assignments, tests, or notes.

Student Assessment. Students should know what work would be expected over the course of the semester (Table 5 ) and how they will be evaluated. A section that explains the types of assignments (such as quizzes, tests, laboratory reports, short papers, term papers, reflective journals or blogs, class participation, and written summaries) and the weight or point value assigned to each should be a dedicated section of the syllabus or should be combined with the section on how grades are calculated.

If you have written assignments such as journal article reviews, laboratory reports, or topical papers, you may include any guidelines on how they should be completed as part of the syllabus or as separate documentation handed out in class or posted to the web or course management system. Horticulture faculty need to train students how to write for the discipline by having students write using the language of the discipline. We cannot expect our colleagues in the English department to teach to each discipline's style. Employers expect graduates to be able to locate, read, analyze, and synthesize information.

As the instructor of the course, you can guide students in using the scientific literature by specifying the types of references you will accept in papers or laboratory reports. Specify how you will handle spelling and grammar errors when grading. While a graduate student, I had a professor who deleted one point for each spelling error on quizzes. I quickly learned to study the spelling of new technical terms and checked spelling before turning in the quiz. On any paper written for one of my courses, I assign two grades - one for horticultural content and one for proper grammar and spelling. Once I instituted this practice, the quality of the writing improved.

GRADES AND GRADING SCALE. With the syllabus, students are made aware of the value of each assignment, quiz, examination, and other assessments of student learning, as well as the value of attendance. A related course component is grading. The grading scale and any policy on late assignments are included in the section on grading.

Students come from many different high school environments and educational cultures. Explain how you do things; do not assume students know this up front. It is your responsibility to explain your philosophy of student evaluation. Regardless of how you grade, an explanation should be 
Table 6. Presentation of textbooks and other readings from syllabus for a course that does not require a textbook and from one that does.

From a course syllabus with no textbook required

There is no required textbook for this course. Over the 5 weeks, I will post reading materials to the course management system and expect that you will read these before coming to class. I will also post a PDF file of the class session PowerPoint ${ }^{\mathrm{z}}$ to aid in the discussion of the topic during class. I will also provide examples of materials we discuss or other documents to provide you with support information.

From a course syllabus with a required textbook

Plant Pathology Concepts: Concepts and Laboratory Exercises (second ed.; ISBN: 9781420046694) Robert N. Trigiano, Mark T. Windham, and Alan S. Windham. 2008. CRC Press. This textbook is required and readings will be assigned. Your knowledge and comprehension of assigned readings will be evaluated on lecture exams.

${ }^{\mathrm{z}}$ Microsoft Office PowerPoint, Microsoft Inc. (Redmond, WA).

provided on the course syllabus. If you award points for each assignment, test, quiz, etc., and then assign grades based on the percentage of total available points, you should explain that. Students have the right to know how the final grade for the course is determined. In addition to being ethical, it is also useful to have a record of grade calculation in writing should the student appeal the grade awarded. Your decision and actions are more easily supported if you have a clear policy.

The University of Tennessee does not have a preset grading scale. Therefore, an instructor has the flexibility to set their breakpoints for the various grades. Some institutions and/or departments may have a set scale. Most universities in the United States record letter grades of A, B, C, $\mathrm{D}$, and $\mathrm{F}$; some include pluses and minuses. If you are new to an institution, ask your department head/chair or a colleague what the institution's grading system includes. Some will require that you use the full array of available grades (the plus and minus versions of the grades), and others have predefined breakpoints for the various grades.

If you reduce the maximum points awarded on late work, try to present your policy in a positive way. Rather than stating that students will lose $10 \%$ of the total points for late assignments, reverse that and say that the student is eligible for $90 \%$ of the total points. According to work cited by Wasley (2008), students perceived the wording in the second statement to be from an instructor who is more approachable and would be more willing to discuss problems with that instructor.

TEXTBOOK AND OTHER READINGS. If you require a textbook, make sure you actually use the book. Provide a complete citation of the required textbook and other readings that come from journals or other sources (Table 6). A complete citation includes the International Standard Book Number (ISBN), “.... 13digit number that uniquely identifies books and book-like products published internationally." It establishes and identifies "...one title or one unique edition of a title from one specific publisher..." (Bowker, 2008). University bookstores commonly require you to provide the ISBN so they can order the correct edition; providing the ISBN to students ensures they can order the correct edition from online outlets or other vendors.

If your course relies heavily on journal articles, it may not always be possible to provide these ahead of time because you may want to use new research released during the course of the semester. In such cases, especially with upper division and graduate-level courses, a statement should be included that readings will be assigned throughout the semester, and when possible, posted on the course management system site.

One final note about textbooks: some universities have begun to implement new textbook order processes due to concerns over high textbook prices. Over the past couple of years, the halls of Congress and state capital buildings resonated with debate over the escalating cost of textbooks. The target of the discussions was not the universities, but rather the textbook publishers. As a result, some states and the Federal government have initiated or passed legislation with the intent of reducing textbook costs for students (Field, 2008; Hebel, 2006a, 2006b, 2008; Lipka, 2008; Smith, 2007; Tennessee Legislature, 2007) by restricting the bundling of books with other materials, by requiring faculty to acknowledge they know the price of the books they assign, or by requiring faculty to select lower-cost alternative books if the content is the same and meets the course objectives.

\section{Conclusion}

Preparing a course syllabus allows you to think about the course you are preparing to teach. It allows you to organize learning objectives, teaching methods, and student assessment within the time allowed for the course, whether a semester or quarter or other time period. The syllabus also allows you to initiate a discussion at the beginning of the semester about the important aspects of the course. You may also refer to the syllabus throughout the term. The syllabus becomes the road map for the course and provides you with a way to present your philosophy of teaching to your students. Perhaps the most important role of the wellwritten syllabus is to represent you to your students as a teacher, a facilitator, and a mentor.

\section{Literature cited}

Bowker, R.R., LLC. 2008. ISBN (International Standard Book Number). 11 Nov. 2008. <http://www.bowker.com/ index.php/identifier-services/book-titleidentifiers-isbn $>$.

D'Antonio, M. 2007. If your syllabus could talk. Chronicle Higher Educ. 21 Aug. 2008. <http://chronicle.com/ jobs/news /2007/07/2007071901c/ careers.htm>.

Field, K. 2008. Long-overdue highereducation bill is close to becoming law. Chronicle Higher Educ. 21 Aug. 2008. $<$ http://chronicle.com/daily/2008/ 08/4077n.htm>.

Hebel, S. 2006a. State Digest: A bid to restrict abortion coverage for students in 
Kansas, and news from other states. Chronicle Higher Educ. 21 Aug. 2008. <http://chronicle.com/daily/2006/ 02/2006021007n.htm>

Hebel, S. 2006b. State Digest: Opposition to in-state tuition for immigrants in Utah, and other news from the states. Chronicle Higher Educ. 21 Aug. 2008. <http://chronicle.com/daily/2006/ 06/2006062308n.htm>.

Hebel, S. 2008. With compromises, higher-ed bill could move through Congress this week. Chronicle Higher Educ. 21 Aug. 2008. <http://chronicle.com/ daily $/ 2008 / 07 / 3984$ n.htm $>$.

Hess, J.L. and M.S. Whittington. 2003. Developing an effective course syllabus. North Amer. College Teachers Agr. J. $47(3): 23-27$.
Lipka, S. 2008. House bill proposes disclosure rule to control textbook prices. Chronicle Higher Educ. 21 Aug. 2008. <http://chronicle.com/daily/2008/ 01/1465n.htm>.

Smith, L. 2007. Publishers and students demonstrate opposite views on textbook pricing at Capital Hill briefing. Chronicle Higher Educ. 21 Aug. 2008. <http:// chronicle.com/daily/2007/07/ 2007071106n.htm>.

Taylor, M.L. 2006. Generation NeXt comes to college: 2006 Updates and emerging issues. 11 Nov. 2008. <http:// www.taylorprograms.org/images/Gen_ NeXt_article_HLC_06.pdf>.

Tennessee Legislature. 2007. House Bill No. 1257/Senate Bill No. 2076, Tennessee Code Annotated, Title 49, Chapter 7,
Part I, Subsection 49-7-1 (a), passed 31 May 2007, approved 22 June 2007. 22 Aug. 2008. <http://www.legislature.state. tn.us/bills/currentga/Chapter/PC0504. pdfs.

Trigiano, R.N., M.T. Windham, and A.S. Windham. 2008. Plant pathology concepts: Concepts and laboratory exercises. 2nd ed. CRC Press, Boca Raton, FL.

University of Tennessee. 2008. Hilltopics: Student handbook 2008-2009. 21 Aug. 2008. <http://dos.utk.edu/hilltopics/>

Wasley, P. 2008. Research yields tips on crafting better syllabi. Chronicle Higher Educ. 14 Mar. 2008. <http:// chronicle.com/weekly/v54/i27/ 27a01101.htm> 